\title{
PEMBANGUNAN BERBASIS GENDER
}

\author{
Restu Pauzia
}

\begin{abstract}
Humans are social beings who live in groups and form an order of social life such as building a country. One of the ways that the government takes to realize the welfare of its people is through development. With development, the right to welfare for the whole community can be achieved. The concept of welfare in development is not seen as the same thing. Every society in this world has a different level of wealth. This is because they do not only take into account gender differences, but also all vulnerable groups. Basically, development is held for improvement. This means the desire to grow based on individual or group strengths depends on the situation and condition of human labor and social structure. When viewed from the development process to date, there are still many disadvantages for vulnerable groups who also participate in economic growth in the community. Gender perspective is very important in determining policies that will be implemented for the development to the process and results, especially laws which do not regulate detrimental losses to vulnerable groups. This shows that women and other vulnerable groups should receive special attention in the development because they are at a higher risk of physical and non-physical violence.
\end{abstract}

Keywords: Development, Gender

\section{PENDAHULUAN}

Manusia adalah mahluk sosial yang membutuhkan satu sama lain untuk mengembangkan kehidupannya. Manusia akan membentuk kelompok dengan tujuan yang sama serta bersama-sama berusaha mencapai tujuan. Terbentuknya negara dengan tujuan yaitu dapat memberikan hak setiap warga atau masyarakat yang ada di dalam wilayahnya serta memberikan kesejahteraan hidup bagi seluruh masyarakat. Salah satu jalan yang ditempuh pemerintah agar dapat mewujudkan keduanya yaitu melalui pembangunan. Dengan adanya pembangunan maka hak setiap warga atau masyarakat dan kesejahteraan hidup bagi seluruh masyarakat dapat tercapai. Dapat dilihat kesuksesan sebuah Negara dari proses pembangunannya. 
Membangun Negara berdasarkan tujuannya perlu dimulai dari hal yang kecil seperti desa, jika desa dapat berkembang dan bahkan maju maka dapat dikatakan negaranya juga berkembang atau maju. Begitupun sebaliknya apabila desa tertinggal maka dapat dipastikan negaranya juga menjadi Negara yang tertinggal. Perencanaan untuk membangun sebuah wilayah adalah kunci kesuksesan bagi Negara di masa yang akan datang. Jika sesuatu hal yang dimulai tanpa adanya perencanaan yang matang, maka apa yang dikerjakan pun tidak sesuai hasil yang diharapkan dan begitu juga yang terjadi dalam pembangunan serta tidak mensejahterakan semua warga Indonesia terutama mereka yang berada pada wilayah pembangunan.

Konsep kesejahteraan dalam pembangunan tidak dipandang sebagai satu hal yang sama. Setiap masyarakat yang ada di dunia ini mempunyai tingkat kesejahteraan yang berbeda-beda. Hal ini disebabkan bukan hanya karena tidak mempertimbangkan perbedaan jenis kelamin tetapi juga tidak mempertimbangkan semua kelompok-kelompok rentan. Untuk memahami sejahtera atau tidaknya seseorang dapat dilihat dari bagaimana pencapaian tujuan yang lebih penting dilakukan dengan menggunakan alat dan bahan yang berkualitas serta mempertimbangkan segala aspek fungsi dan penggunanya.

Langkah awal yang dilakukan pemerintah dalam membangun memang dimulai dari bagaimana mengelola semua sumber daya yang ada dengan perencanaan yang matang dengan harapan memberikan manfaat bagi masyarakat luas. Selama ini, pembangunan yang ada baik di tingkat desa maupun kota mulai menunjukkan hasil yang nyata dan dapat dirasakan bagi semua masyarakat. Namun adanya perencanaan yang keliru dalam merencanakan pembangunan tersebut yakni menghiraukan hak laki-laki dan perempuan secara berbeda. Selain itu, perencanaan pembangunan mengabaikan kelompok-kelompok rentan seperti; kelompok wanita, anak-anak, lansia, disabilitas, dan orang dalam gangguan jiwa (ODGJ) yang pada akhirnya menyebabkan terjadinya ketimpangan atau ketidaksetaraan gender. 
Tidak hanya kaum perempuan, tetapi kelompok rentan lainnya juga memiliki potensi yang sama besarnya mendapatkan perlakuan yang diskriminatif, meskipun ada kemungkinana laki-laki juga akan mengalami hal serupa. Namun, selama ini, memang kelompok rentan tersebutlah paling banyak yang menjadi korban dibandingkan laki-laki. Namun norma-norma dan nilai-nilai yang dianut masyarakat yang cenderung patriarki masih membatasi ruang gerak perempuan. Sehingga banyak batasan-batasan yang dimiliki kelompok perempuan untuk ikut serta dalam proses perencanaan dan proses pembangunan. Padahal, prinsip dasar dari pembangunan adalah mensejahterakan seluruh masyarakatnya dengan mempertimbangkan perbedaan yang responsive gender. Oleh sebab itu, seharusnya semua unit dan kelompok tersebut terlibat bersama dalam seluruh tahapan perencanaan, penganggaran, pelaksanaan hingga pemantauan hasil pembangunan di wilayah tersebut.

\section{KAJIAN TEORI}

\section{Konsep Dasar Pembangunan}

Para ahli memberikan pendapatnya tentang teori pembangunan yang dapat dikelompokkan dalam dua paradigm, yakni Modernisasi dan ketergantungan. Di dalam paradigm modernisasi termasuk teori-teori makro tentang pertumbuhan ekonomi dan pertumbuhan sosial, dan mikro tentang nilai-nilai individu yang menunjang proses perubahan tersebut. Sedangkan paradigm ketergantungan mencakup teori-teori keterbelakangan (Underdevelopment), ketergantungan (Dependent Develepment), dan sistem dunia (World System Theory) sesuai dengan klasifikasi Larrain tahun 1994. ${ }^{1}$

Pembangunan memiliki defenisi yang bersifat dinamis, sehingga tidak bisa dipandang dari konsep yang statis. Pembangunan mengandung orientasi dan aktivitas yang berkelanjutan tanpa ada batas yang mana pada proses pembangunannya mengalami banyak perubahan seperti sosial dan budaya. Pada dasarnya pembangunan dilakukan untuk meningkatkan sesuatu hal yang

\footnotetext{
2019), 1 .

${ }^{1}$ Kumba Digdowiseiso, Teori Pembangunan, (Cet. I; Jakarta: Katalog Dalam Terbitan,
} 
diinginkan. Artinya keinginan untuk lebih maju berdasarkan kekuatan individu atau kelompok, tergantung situasi dan kondisi tenaga manusia dan struktur sosialnya.

Kecenderungan globalisasi dan regionalisasi mambawa banyak tantangan dan peluang baru bagi proses pembangunan di Indonesia dalam segala bidang. Di era saat ini, fenomena persaingan antar pelaku ekonomi, politik dan bahkan bidang pendidikan semakin tajam. Semakin kerasnya keinginan untuk maju, maka semakin banyak usaha yang harus dilakukan demi mewujudkannya. Dalam konteks persaingan yang tajam, setiap orang dituntut untuk menerapkan dan mengimplementasikan secara efektif dan efisien dalam membantu pembangunan tersebut.

Dalam hal ini, pembangunan dapat diartikan sebagai suatu upaya terkoordinasi untuk menciptakan alternative yang jauh lebih banyak secara sah kepada setiap warga Negara untuk memenuhi dan mencapai aspirasinya yang paling manusiawi (Nugroho dan Rochmin Dahuri, 2004). Secara umum disepakati bahwa pembangunan merupakan proses untuk melakukan perubahan. Siagin juga memberikan pandangannya tentang pembangunan yakni sebagai suatu usaha atau rangkaian usaha pertumbuhan dan perubahan yang berencana dan dilakukan secara sadar oleh suatu bangsa, Negara dan pemerintah, menuju modernitas dalam rangka pembinaan bangsa (notion bulding). Selain itu, Ginanjar Kartasasmita mengatakan bahwa pembangunan secara sederhana ialah suatu proses perubahan kea rah yang lebih baik melalui upaya yang dilakukan secara terencana. ${ }^{2}$

Pikiran awal tentang pembangunan biasa ditemukan gagasan yang lebih mengarah pada pembangunan dengan perkembangan atau pembangunan dengan modernisasi, industry dan bahkan westernisasi yang mana pemikiran tersebut mengarah pada adanya inovasi pembangunan segala bidang yang lebih maju. Pembangunan harus berjalan dengan mencakup di dalamnya seluruh aspek kehidupan manusia yang diencanakan sedemikian rupa hingga memperbaiki tatanan kehidupan bermasyarakat. 
Berbagai cara dapat diupayakan jika ingin membangun sebuah tatanan kehidupan masyarakat, seperti ditingkat desa untuk mewujudkan kesetaraan gender . Upaya tersebut dapat dilakukan secara individu, kelompok bahkan oleh negara. Dan upaya-upaya tersebut dapat diarahkan untuk mewujudkan pembangunan yang responsif gender dan juga menjamin hak-hak masyarakat.

Kata pengembangan mengacu pada seluruh aspek dalam hidup manusia yang selalu mengalami perubahan. Manusia tentu memiliki tujuan di dalam hidupnya dan melakukan berbagai macam cara untuk mewujudkannya baik secara per individu maupun kelompok. Pada dasarnya pembangunan melalui proses yang sangat kompleks, dijalankan secara terus-menerus untuk mengembangkan negara dan selalu ditingkatkan. Pada prosesnya, pembangunan memiliki banyak unsur yang saling terkait untuk mewujudkan pembangunan yang dapat berfungsi sesuai dengan tujuan dibangunnya dan memiliki banyak kegunaan bagi masyarakat luas. Semakin berkembangnya zaman, bangunan semakin banyak menghiasi setiap daerah di berbagai wilayah yang tentunya ini adalah kebutuhan manusia sebagai bentuk dari upaya mengembangkan kehidupan kea rah yang lebih baik. Bangunan yang dimaksudkan berupa lembaga pendidikan, ekonomi, politik, dan sosial.

Hubungan manusia dan pembangunan akan membentuk sebuah pola atau model pembangunan yang berjalan sebagaimana semestinya. Pertumbuhan ekonomi, pendidikan serta demokrasi menjadi lebih berkembang untuk kepentingan Negara. Berdasarkan model pembangunan dapat menjelaskan beberapa tipe pembangunan yang memiliki beberapa macam pola dasar pembangunan berdasarkan tujuan pembangunan di masing-masing nerga. Berikut ini UNDP menjelaskan bahwa terdapat empat macam model pembangunan yakni:

Saat ini, pembangunan harus memiliki standar yang harus terpenuhi sesuai dengan undang-undang dan peraturan pemerintah daerah serta memiliki izin untuk melaksanakannya. Selain itu, pembangunan harus melihat kebutuhan yang menjadi pembeda antara perempuan dan laki-laki. Tidak hanya persoalan jenis kelamin saja, melainkan bagaimana pembangunan itu memprioritaskan kelompokkelompok rentan misalnya; perempuan, anak-anak, lansia, penyandang disabilitas, 
232 | MUSA WA, Vol. 13 No.2 Desember 2021 : 227-242

orang dalam gangguan jiwa (ODGJ) dan kelompok lainnya yang membutuhkan perhatian lebih.

Pemerintah Indonesia adalah penegak hukum yang mengambil keputusan yang harus mampu membuka mata secara luas dan peka terhadap mereka yang memang membutuhkan perlindungan untuk mewujudkan hak bagi setiap warga negara yakni merasa aman dan sejahtera. Hal ini pula tidak hanya menyangkut situasi hidup saat ini, melainkan juga menyangkut situasi di masa yang akan datang. Terlebih lagi pembangunan berkaitan erat dalam hidup manusia dalam segala aspek terutama aspek pendidikan sangat berkaitan dengan masa depan kehidupan berbangsa dan bernegara. Maka dari itu, perlu senantiasa mengupayakan intropeksi dan meningkatkan pembangunan sejalan dengan tuntutan kehidupan masyarakat yang semakin tinggi.

Beranjak dari majunya hidup sosial yang dijalani manusia dalam bermasyarakat, ilmu pengetahuan dan teknologi pun semakin berkembang yang menunjukkan semakinbesar kebutuhan setiap individu terhadap perubahan dari implementasi pembangunan terhadap pendidikan yang menjadi pion untuk memajukan dan mensejahterakan kehidupan bangsa. Untuk itu, masyarakat memberikan harapan besar pada anak-anak mereka untuk bersekolah agar menjadi seseorang yang cerdas, pandai, memiliki akhlak yang baik, bertanggung jawab, berguna untuk agama, bangsa dan negara. Harapan itu tertanam hampir disetiap orang yang memikirkan jangka panjang kedepan yang diinginkan semakin baik. Perilaku manusia yang menginginkan kehidupan yang lebih baik atau lebih layak dalam jangka panjang inilah sebagai dorongan manusia untuk bertindak dan berperilaku.

Berkaitan dengan hal tersebut, manusia perlu belajar dan memperbaiki perencanaan pembangunan yang lebih matang, supaya mampu mengikuti zaman yang semakin maju. Mulai dari perencanaan pembangunan sampai pada tahan hasil akhir pembangunan banyak interaksi yang diperlukan manusia untuk mewujudkannya. Karena manusia adalah makhluk sosial yang tidak dapat hidup 
sendiri tanpa bantuan manusia lainnya dan membutuhkan interaksi dalam berbagai lingkungan untuk apapun yang dilakukannya. Interaksi sosial tidak terlepas dari lingkungan kehidupan manusia yang bermacam-macam baik formal, non formal dan informal. Sejak dulu, manusia sangat tertarik untuk memajukan peradabannya dengan pembangunan yang semakin ditingkatkan. Kesadaran seseorang amat penting terhadap persoalan ini, sebab pembangunan perlu direncanakan dan dilakukan dengan memperhatikan keselamatan dan kenyamanan bersama. Kesadaran terwujud dari interaksi yang terjadi dilingkungan dengan menyesuaikan apa yang menjadi kebutuhan masyarakat daerah setempat. Aktivitas lingkungan sangat diperlukan untuk mendukung berbagai perkembangan pembangunan yang ada terutama aspek sosial yang berdampak pada kenyamanan dan keselamatan para penggunanya.

Sejatinya manusia harus melakukan tindakan untuk menunjukkan bahwa tindakan tersebut harus sesuai dengan kriteria atau standar normatif tertentu. Salah satu ciri setiap makhluk adalah melakukan tindakan. Manusia "harus" melakukan tindakan, itu melukiskan eksistensi manusia secara mendalam, karena perbuatan manusia tidak hanya terkait dengan keberadaannya sebagai makhluk, tetapi juga memicu nilai-nilai kemanusiaan. Makna terminologi "harus" mengedepankan pemahaman bahwa tindakan manusia harus memenuhi syarat moral atau etis tertentu. ${ }^{3}$ Oleh karena itu, Pemerintah perlu bertindak dan bekerja sama dengan para ahli dibidangnya yang terkait dengan pembangunan tersebut serta mengikutsertakan kelompok-kelompok rentan untuk mengetahui permasalahan yang seringkali terabaikan oleh pemerintah.

\section{Pembangunan Berbasis Gender}

Istilah gender masih asing bagi sebagian warga Indonesia. Karena istilah gender sendiri adalah bahasa serapan dari bahasa Inggris. pada mulanya konsep gender yang pertama kali disampaikan Anne Oakley yang menggunakan wacana feminisme hanya sebatas memberikan perbedaan jenis kelamin (seks). Perbedaan

\footnotetext{
${ }^{3}$ Agustinus W. Dewantara, Filsafat Moral: Pergumulan Etis Keseharian Hidup Manusia, ed. by Marcell (Yogyakarta: PT. Kanisius, 2017), 9.
} 
234 | MUSA WA, Vol. 13 No.2 Desember 2021 : 227-242

seks ini lebih kepada ciri fisik baik perempuan maupun laki-laki secara biologisnya termasuk organ genetalia. Konsep ini popular di Barat tepatnya Eropa Barat dan Amerika Serikat pada tahun 1970-an. Gender berbeda dengan seks, gender adalah persepsi persepsi sosial dan budaya tentang peran laki-laki dan perempuan dalam sebuah masyarakat. Sedangkan seks ialah nature, gender merupakan hasil dari nature. Dengan kata lain, seks adalah kontruksi alam dan gender adalah konstruksi sosial dan budaya. Namun demikian, pembedaan seks dan gender yang terlihat jelas ini nyatanya menyisakan wilayah abu-abu (grey areas) yang pada gilirannya memicu kontroversi teori feminisme secara umum dan teologi feminis secara khusus. Konsep gender inilah yang kemudian dijadikan alat analisis oleh kelompok feminis pada umumnya untuk melihat ketertindasan perempuan dalam masyarakat, termasuk oleh feminis Indonesia. ${ }^{4}$

Definisi gender juga diartikan sebagai konsep cultural yang berupa membuat perbedaan dalam hal peran, perilaku, mentalitas, dan karakteristik emosional antara laki-laki dan perempuan yang berkembang dalam masyarakat (Woman's Studies Encyclopedia). ${ }^{5}$

Pembangunan merupakan suatu proses perubahan yang ditujukan untuk meningkatkan kualitas hidup manusia. Pada prosesnya, pembangunan di suatu negara tidak terlepas dari pengaruh sumber daya manusia sebagai pelaku yang ada di dalamnya. Menurut Tikson (2005), salah satu tolok ukur dari tingkat keberhasilan pembangunan suatu wilayah adalah pembangunan manusia yang dimilikinya. Jadi, pembangunan yang berbasis gender adalah proses perubahan kehidupan manusia tanpa adanya perbedaan, diskriminasi dan kekerasan untuk mewujudkan kehidupan bermasyarakat yang lebih baik.

Pada negara yang memiliki tingkat pembangunan manusia yang tinggi, terkadang masih ada ketimpangan pada pembangunan yang membedakan laki-laki dan perempuan. Jika melihat hakekat keberhasilan pembangunan yang

${ }^{4}$ Muh. Tasrif, Teologi Gender dalam Islam: Esai Bibliografis Karya-Karya Intelektual Muslim Indonesia, Dialogia Jurnal Studi Islam dan Sosial (Ponorogo: Jurusan Ushuluddin STAIN Ponorogo, 2003), 1-2.

${ }^{5}$ Rilla Sovitriana, Kajian Gender dalam Tinjauan Psikologi, (Cet.I; Ponorogo: Uwais Inspirasi Indonesia, 2020), 8. 
dilaksanakan sangat tergantung pada peran serta seluruh penduduk, baik laiki-laki maupun perempuan. Artinya, adanya kesetaraan gender yang terjadi mulai dari perencanaan sampai hasil akhir pembangunan tersebut.

Dalam hal ini akan muncul berbagai perbedaan, antara lain perbedaan gender: "Gender diproduksi dan direproduksi dalam berbagai bentuk partisipasi dalam komunitas praktik tertentu. Ketika komunitas praktik dipersatukan dalam seluruh komunitas praktik, di antara mereka hubungan juga dapat mengarah pada pengawasan gender. Individu berpartisipasi dalam berbagai komunitas praktik, dan komunitas ini berinteraksi dengan komunitas lain dalam berbagai cara. Karena proses partisipasi dan interaksi terus berubah, identitas pribadi dan berbagai identitas kelompok, termasuk identitas gender, juga terjadi diciptakan kembali.

Dalam masyarakat di mana stratifikasi tidak begitu ketat dan peran lakilaki dan perempuan tidak dibedakan dengan jelas, kita dapat berharap untuk menemukan refleksi dari situasi ini dalam bahasa yang digunakan. Sebagian besar perbedaan dapat dijelaskan oleh perbedaan posisi yang dipegang oleh pria dan wanita dalam masyarakat. Pria memiliki lebih banyak kekuatan dan mungkin lebih percaya diri; wanita sering dibiarkan di tempat, tetapi mereka sering menginginkan tempat yang berbeda dan lebih baik. Akibatnya, perempuan tampaknya lebih sadar akan penggunaan bahasa yang mereka asosiasikan dengan atasan mereka di masyarakat, yaitu orang yang mereka anggap superior secara sosial. Oleh karena itu, mereka mengarahkan percakapan ke model yang disediakan, bahkan dalam situasi tertentu yang terlalu banyak dikoreksi. Oleh karena itu, perempuan seringkali menjadi yang terdepan dalam perubahan norma sosial kelas atas, sedangkan perempuan kelas menengah dan bawah berada di barisan terdepan.

Berdasarkan fenomena yang terjadi, terlihat bahwa laki-laki masih dominan di masing-masing indikator, baik ketenagakerjaan, pendidikan, kesehatan maupun keterwakilan di parlemen. Perbedaan yang jauh terlihat jelas pada indikator rasio keterwakilan perempuan terhadap laki-laki di parlemen sehingga menyebabkan nilai IKD yang tinggi. Dapat dikatakan bahwa 
keterwakilan perempuan di parlemen untuk hampir semua negara masih rendah. Proporsi perempuan sebagai pemimpin dan pengambil keputusan masih belum sesuai. Hal ini terlihat dari masih sedikitnya peran perempuan.

Perbedaan jenis kelamin dalam tingkah laku interpersonal lainnya juga dapat dijelaskan melalui perbedaan evolusi. Sebagai contoh, wanita lebih cenderung menyadari emosinya dibandingkan pria. Namun kemungkinannya bisa jadi sama yakni wanita adalah subjek terhadap tekanan sosial yang mendorong mereka untuk memperjuangkan kerja sama dan kemurahan hati dari pada kompetisi keegoisan.

Permpuan atau laki-laki dalam mewakili kelompoknya menunjukkan semakin setara dalam pengambilan keputusan. Misalnya saja wanita dan pria sebanding dalam menduduki parlemen untuk pengambil keputusan dan kebijakan maka dapat mengutarakan dari berbagai sisi pembangunan yang seperti apa seharusnya dilaksanakan sehingga semua kelompok dapat seiring sejalan.

Pada pembahasan ini, gender tidak hanya tentang perbedaan jenis kelamin tetapi juga kelompok rentan yang memungkinkan menjadi korban kekerasan kapanpun dan dimanapun. Adapun kelompok rentan tersebut ialah; kelompok perempuan, anak-anak, disabilitas, lansia, dan orang dalam gangguan jiwa (ODGJ). Realitasnya menunjukkan bahwa pembangunan tidak dapat dipisihkan dengan manusia karena manusia adalah penggerak dalam majunya kehidupan peradaban. Namun, sering kali pembangunan kurang memperhatikan perbedaan gender baik dari jenis kelamin maupun kelompok-kelompok rentan tersebut.

Permasalahan gender sesungguhnya sudah lama menjadi perhatian negaranegara di dunia. Hal ini terlihat dengan dicetuskannya The Universal Declaration of Human Rights (Deklarasi Universal Hak Asasi Manusia), oleh Majelis Umum PBB di tahun 1948 yang kemudian diikuti oleh berbagai deklarasi serta konvensi lainnya. Pada tahun 1979 Majelis Umum PBB mengadopsi konvensi Penghapusan Segala Bentuk Diskriminasi terhadap perempuan (Convention on the Elimination of All Forms of Discrimination Against Women) yang menjadi landasan hukum tentang hak perempuan. Konvensi tersebut disebut juga Konvensi Wanita atau 
Konvensi CEDAW (Committee on the Elimination of Discrimination Against Women). Selanjutnya, Hak Asasi Perempuan kembali dideklarasikan dalam Konferensi Dunia ke-IV tentang Perempuan di Beijing tahun 1995. Konferensi tersebut mengangkat 12 bidang yang menjadi keprihatinan Negara-negara di dunia, mencakup:

1. Perempuan dan Kemiskinan;

2. Pendidikan dan Pelatihan Bagi Perempuan;

3. Perempuan dan Kesehatan;

4. Kekerasan Terhadap Perempuan;

5. Perempuan dan Konflik Bersenjata;

6. Perempuan dan Ekonomi;

7. Perempuan dan Kekuasaan serta Pengambilan Keputusan;

8. Mekanisme Kelembagaan Untuk Kemajuan Perempuan;

9. Hak Asasi Perempuan;

10. Perempuan dan Media;

11. Perempuan dan Lingkungan Hidup; serta

12. Anak Perempuan. ${ }^{6}$

Data terpilah juga harusnya memasukan beberapa kelompok rentan lainnya seperti penyandang disabilitas, lansia dan bahkan Orang Dalam Gangguan Jiwa (ODGJ). Publikasi tersebut menekankan bahwa pembangunan manusia merupakan upaya untuk memperluas pilihan bagi semua masyarakat, bukan hanya salah satu bagian dari masyarakat sehingga tidak ada masyarakat yang terkecualikan. Dalam publikasi tersebut juga tersirat pesan bahwa pengabaian aspek gender akan menghambat proses pembangunan di suatu wilayah. Artinya, semua pembangunan yang ada harus mempertimbangkan semua orang yang menggunakan hasil dari pembangunan tersebut dengan nyaman dan aman, sehingga tujuan dan fungsi pembangunan dapat tercapai dengan maksimal.

Data-data terpilah menjadi solusi yang dapat dilakukan untuk mengevaluasi sejauh mana peraturan undang-undang tersebut telah tesponsif 
238 | MUSA WA, Vol. 13 No.2 Desember 2021 : 227-242

gender yang mendukung pengurusutamaan gender. Indikator yang menunjukkan capaian pembangunan berbasis gender akan memberikan gambaran yang nyata tentang pengarusutamaan gender di Indonesia. Diharapkan dengan adanya keterbukaan data terpilah digunakan sebagai pembuka wawasan tentang pembangunan yang responsive gender.

Tingkat keberhasilan pembangunan tidak responsive gender jauh lebih kecil bila dibandingkan dengan pembangunan yang sudah responsive gender. Ini terlihat dari pemanfaatan bangunan yang dibuat sehingga banyak orang yang dapat memfungsikannya tanpa terkecuali sehingga adanya diskriminasi dan tindakan kekerasan yang dialami oleh para kelompok rentan.

Diskriminasi terhadap kelompok rentan dalam berbagai hal di kehidupan bermasyarakat dan pembangunan sangat terlihat perbedaan capain jenis kelamin dan kelompok rentan. Di daerah yang masih kental akan budaya patriarki, perempuan umumnya lebih tertinggal dibandingkan laki-laki baik dari aspek pendidikan, ekonomi dan juga kesehatan. Hal ini karena adanya norma dan nilainilai yang ada pada budaya yang telah berlangsung sejak lama dan tentunya sangat merugikan kelompok rentan dan menempatkannya pada posisi dibawah.

Jika dilihat dari proses pembangunan sampai saat ini, masih banyak merugikan kelompok-kelompok rentan yang juga ikut serta dalam pertumbuhan perekonomian di masyarakat. Kelompok perempuan yang merupakan salah satu kelompok rentan banyak mengambil peran ganda yakni sebagai ibu rumah tangga yang mengurus segala keperluan keluarga di rumah dan sebagai pencari nafkah demi membantu perekonomian keluarga. Mereka terjun dalam dunia tersebut dikarenakan tuntutan kebutuhan hidup semakin meningkat. Adanya sektor unggulan akan sangat membantu dan memudahkan perencana wilayah dalam menyusun untuk pengembangan pembangunan daerah. Dalam perkembangannya, sektor unggulan ini dapat mengalami kemajuan dan juga kemunduran. Hal tersebut tergantung pada usaha-usaha yang dapat meningkatkan peran sektor unggulan tersebut. 
Selain perekonomin, perempuan dan kelompok rentan lainnya juga di nomor duakan dalam aspek pendidikan. Pembangunan yang difungsikan sebagai lembaga pendidikan formal tidak membedakan antara kebutuhan perempuan, lakilaki, penyandang disabilitas dan lainnya. Misalnya toilet umum perempuan dan laki-laki disamakan sehingga memicu munculnya tindak kekerasan atau pelecehan pada perempuan.

Sedangkan bagi para penyandang disabilitas sering kali kesulitan untuk mengakses toilet umum dengan mudah. Harus di tuntun oleh orang lain, padaha; pembangunan tersebut harusnya dapat memprioritaskan perbedaan para penggunanya demi kenyamanan dan keselamatan.

Perspektif gender sangat penting di dalam pemutusan kebijakan yang akan dilaksanakan untuk pembangunan, terutama dalam undang-undang yang mengatur tidaklah merugikan kelompok rentan tersebut. "menurut Himawan, dalam rencana pembangunan jangka menengah nasional (RPJMN) 2020-2024, pengarusutamaan gender menjadi salah satu strategi pembangunan."7 Hal ini menunjukkan bahwa perempuan dan kelompok rentan lainnya memang perlu memiliki perhatian khusus di dalam pembangunan karena posisi yang memiliki resiko tinggi terhadap tindak kekerasan baik secara fisik maupun non fisik.

Tujuan utama dari pembangunan adalah menciptakan lingkungan yang memungkinkan bagi rakyatnya untuk menikmati ketenangan hidup dalam bersosial, dan menjalankan kehidupan yang produktif. Hal ini tampaknya merupakan suatu kenyataan sederhana tetapi sering terlupakan oleh berbagai kesibukan jangka pendek untuk mengumpulkan harta dan uang. Terlihat pada pembangunan saat ini masih banyak mengabaikan kepentingan jangka panjang yang seharusnya menjadi prioritas dalam perencanaan hingga sampai pada hasil akhir pembangunan.

Mengukur indeks ketimpangan memang menjadi hal yang paling penting sebab dapat diklasifikasikan dengan tolok ukur kesehatan, pendidikan dan standard hidup layak setiap orang dimana di dalamnya juga termasuk terhindar

\footnotetext{
${ }^{7}$ Isi pidato yang disampaikan dalam pembukaan Konferensi Nasional "Sinergi Multipihak untuk Kesetaraan Gender dan Pemberdayaan Perempuan" konferensi ini diadakan oleh MAMPU di Jakarta pada Rabu, 27 November 2019.
} 
dari intimidasi dan kekerasan secara fisik dan non fisik. Oleh karena itu, indeks ketimpangan gender dirancang untuk meningkatkan kesadaran akan adanya ketidaksetaraan gender yang selama ini ada di masyarakat, serta mengetahui kemajuan pembangunan akibat adanya ketidaksetaraan gender. Selain itu pertimbangan yang dilakukan berguna untuk mendukung aksi masyarakat dunia akan kesetaraan gender. Dengan data yang ada, maka dapat membantu pembuatan keputusan dan kebijakan pemerintah nasional dan internasional untuk menghilangkan kesenjangan gender dan adanya kesetaraan gender sehingga menuju pembangunan yang lebih baik di masa mendatang.

Jika mendengar kata kesetaraan maka mengarah pada hal yang seimbang atau memiliki kedudukan yang sama. Kesetaraan sendiri hadir dalam beragam bentuk di kehidupan manusia. Banyak yang mengartikan kesetaraan gender hanya sebatas melihat jenis kelamin wanita dan pria tanpa memikirkan terhadap kelompok rentan lainnya seperti anak-anak, lansia, disabilitas dan lainnya. Disinilah problematika gender tentang penerapan konsepnya dengan benar.

Kesetaraan gender itu sendiri dipahami sebagai suatu bentuk di mana lakilaki dan perempuan memperoleh hak dan kesempatan yang sama di bidang ekonomi, pendidikan, sosial budaya, keamanan, dan penikmatan hasil pembangunan yang sama. Semua individu, termasuk pria dan wanita, memiliki hak untuk hidup. Pekerjaan yang layak tanpa distigmatisasi Laki-laki lebih mampu melakukan banyak pekerjaan daripada perempuan. Sebenarnya mudah bagi kita untuk menerapkan konsep kesetaraan dan rasa hormat gender, tetapi banyak orang telah mencapainya, dan masih banyak kasus diskriminasi dan perilaku kekerasan lainnya yang tajam. Sudah termasuk dalam pengenalan atau salah satu tujuan yang harus dicapai dalam tujuan pembangunan berkelanjutan yang dirancang oleh PBB.

Zaman semakin berkembang dan maju dengan didukung oleh berbagai teknologi dalam membantu pembangunan yang ada saat ini memang dapat diakui semakin canggih. Tapi hal tersebut tidak menjadi tolok ukur manusia untuk berpikir sama bahwa apa yang sudah dilakukan dan dibangun tersebut bisa tidak 
dapat digunakannya karena berbagai factor. Misalnya saja pembangunan tidak melihat perbedaan antara kebutuhan laki-laki dan perempuan sehingga hilangnya kesetaraan gender dalam pembangunan. Terlebih lagi saat ini, perilaku diskriminasi tidak mengenal lingkungan, dimana saja bisa terjadi diskriminasi yang berujung pada tindakan kekerasan.

Bukan hanya itu saja, belakangan ini tatanan pimpinan dalam negara kita sudah cukup baik, bisa dilihat ketika presiden ke-5 Megawati Sukarnoputri menjadi pemimpin perempuan pertama dalam sejarah Indonesia, lalu Sri Mulyani yang mampu mewakilkan Indonesia sebagai direktur pelaksana Bank Dunia atau World Bank di Amerika Serikat. Spekulasi yang melabeli perempuan tidak bisa memimpin ini dipatahkan ketika hadirnya prestasi dari para pemimpin wanita tersebut. Namun demikian, rasanya hal itu belum cukup untuk mengurangi ketidakadilan yang berlaku dalam hirarki gender ini. Banyak penelitian yang mengungkapkan bahwa perempuan kerap menjadi korban utama dalam ketidaksetaraan dan keadilan yang kuat. Pada konsepnya memang laki-laki dan perempuan mempunyai kodrat yang sama tapi pada implementasinya belum sepenuhnya diterapkan terutama dalam pembangunan.

Ruang lingkup sosial budaya bisa mempengaruhi tingkat kemajuan perencanaan pembangunan di masa yang akan datang, semu orang mempunyai hak yang sama untuk ikut serta di dalamnya dan diharapakn bisa menghapus tindakan mengesampingkan kelompok rentan yang berlaku di masyarakat. Yang menjadi permasalahan utama berasal dari biologis gender ini yang mana selalu dihadapkan pada ketidakadilan. Pernyataan ini sudah jelas menekankan bahwa semua individu berhak diperlakukan secara sama tanpa adanya rasa tidak layak atau tersakiti sekalipun dalam hidupnya. Edukasi kesetaraan gender ini yang seyogianya dibutuhkan oleh setiap orang, sebab pentingnya pemahaman ini pada semua orang agar tidak ada lagi diskriminasi di tengah-tengah masyarakat serta mementingkan kelompok rentan dalam pembangunan. 
242 | MUSA WA, Vol. 13 No.2 Desember 2021 : 227-242

\section{KESIMPULAN}

Akhirnya dari tulisan ini dapat disimpulkan bahwa pembangunan bukan hanya untuk orang yang mampu dan memiliki kuasa lebih dibandingkan lainnya tetapi pembangunan untuk seluruh warga masyarakat Indonesia dengan tujuan menjadikan kehidupan masyarakat sejahtera secara keseluruhan tanpa adanya perbedaan, diskriminasi bahkan kekerasan gender. Selain itu, pembangunan harus mengikutsertakan para kelompok rentan dan mempertimbangkan berdasarkan kenyamanan bersama agar pembangunan dapar berjalan dan difungsikan oleh semua orang secara maksimal.

\section{DAFTAR PUSTAKA}

Dewantara, Agustinus W. Filsafat Moral: Pergumulan Etis Keseharian Hidup Manusia, ed. by Marcell, Yogyakarta: PT. Kanisius, 2017.

Digdowiseiso, Kumba. Teori Pembangunan, Cet. I; Jakarta: Katalog Dalam Terbitan, 2019.

https://www.kemenpppa.go.id/lib/uploads/slider/d1ea9-pembangunan-manusiaberbasis-gender.pdf, 2. (diakses pada 05 Desember 2021).

Isi pidato yang disampaikan dalam pembukaan Konferensi Nasional "Sinergi Multipihak untuk Kesetaraan Gender dan Pemberdayaan Perempuan" konferensi ini diadakan oleh MAMPU di Jakarta pada Rabu, 27 November 2019.

Sovitriana, Rilla. Kajian Gender dalam Tinjauan Psikologi, Cet.I; Ponorogo: Uwais Inspirasi Indonesia, 2020.

Tasrif, Muh. Teologi Gender dalam Islam: Esai Bibliografis Karya-Karya Intelektual Muslim Indonesia, Dialogia Jurnal Studi Islam dan Sosial, Ponorogo: Jurusan Ushuluddin STAIN Ponorogo, 2003. 